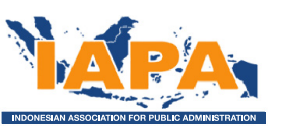

\begin{tabular}{r|r} 
POLICY\&GOVERNANCE & PGR
\end{tabular}

\author{
Dwiyanto Indiahono \\ Department of Public Administration, Faculty of Social and Political Sciences, Universitas Jenderal Soedirman. \\ email: dwiyanto.indiahono@unsoed.ac.id
}

Submitted: 30 June 2020, Revised: 2 March 2021, Accepted: 3 March 2021

\section{Dwiyanto Indiahono is an}

Associate Professor at the Department of Public Administration, Faculty of

Social and Political Sciences, Jenderal

Soedirman University. He obtained

his undergraduate degree from the Public Administration Study Program

of Jenderal Soedirman University, Masters and Doctoral degrees from the Master's Program in Public Administration and the Doctoral Program in Management and Public Policy, Faculty of Social and Political Sciences, Gadjah Mada University. Dwiyanto Indiahono has an interest in research and writing on public policy, bureaucracy, and social capital. One of his books that have been circulated and widely cited is "Public Policy Based on Dynamic Policy Analysis [Gava Media, 2009 \& 2017] and Comparative Public Administration [Gava Media, 2009]".
Policy \& Governance Review ISSN 2580-4820

Vol. 5, Issue 2, pp. 146-163

DOI: https://doi.org/10.30589/pgr. v5i2.347

\title{
Bureaucratic Reform by Building Trust in Citizens: Best Practices from Local Online Complaints
}

\begin{abstract}
The purpose of this study is to provide an overview of the success of the Banyumas Complaint Outlet (Lapak Aduan Banyumas / LAB) in increasing public trust in the government. One of the goals of bureaucratic reform is to build citizens' trust, but it is rarely discussed how the bureaucracy initiates bureaucratic reform by building trust in citizens. This research used qualitative research methods, data collection techniques used are interviews, observation, and documentation. The data analysis techniques used were interactive data analysis and content analysis. $L A B$ offers a framework that gives trust to the public to complain, many complaints from the public will create external pressure from the bureaucracy to make improvements to bureaucratic performance. Performance improvements of the bureaucracy will increase public trust. The increase in public trust in the government is evidenced by the high interest of citizens to provide suggestions and input to the government regarding public services or facilities. A simple complaint system and quick response has proven to strengthen public trust. Bureaucratic reform can be started by earning citizens' trust.
\end{abstract}

\section{Keywords}

Banyumas Complaint Outlet; bureaucratic reform; complaint; public service; trust

\section{Introduction}

Public services are an important sector for citizens. Its monopolistic nature means that citizens have to deal with them periodically or without choice. Public services often neglect to improve their quality, because it is needed by the public. The classical paradigm that places the bureaucracy first in the public sector is no longer relevant because the era has changed.
There has been a change from being initially centered on the state to centering on citizens. The presence of the state by the government is to serve public affairs, therefore the bureaucracy must make citizens the center of its activities. Citizens as the center of public service activities will move the bureaucracy to always learn to improve the quality of its services. This era is shown by the many public 
demands on the bureaucracy. These demands can be translated into aspiration forums in parliament, readers' letters in newspapers, or through social media. All of these media are already common in this digital era.

A good bureaucracy that encourages bureaucratic reform hopes to increase public trust. So far, the available platform is to encourage good bureaucracy to increase public trust. Lanin \& Hermanto's (2019) research for example shows that increasing public satisfaction with basic services can increase public trust in local governments. Whereas in bureaucratic reform, there is something that can hamper the process of excellence in public services, namely the distrust of the government to the public. The government distrusts the citizens which then creates various standards and formal requirements that make it difficult for citizens. This mistrust of public service providers is a serious problem and must be resolved by the bureaucracy. Government agencies must focus on the quality of information and the quality of systems that have a significant relationship with the development of trust (Nulhusna et al., 2017)viz., public participation via continual use intention and electronic wordof-mouth (eWoM.

There are examples of the government building public trust, in fact, there is an interesting activity carried out by the Banyumas Regency Government, which is to open the $L A B$ as a citizen complaint media center online. This media becomes interesting not only because its presence is considered adaptive to the development of digital services, but more than that, this service has changed the mindset that bureaucratic reform can begin by building trust in the public in government services. Nurhidayati's (2019) research shows that online complaints are not only more modern facilities, but with the right complaint handling mechanism, they are also able to promote responsible organizations. Other than that, the mechanism for handling complaints is an efficient instrument that can be used by local heads to monitor the performance of their subordinates (Brennan \& Douglas, 2002; Pramusinto, 2014).

$L A B$ thus becomes interesting to study, how does the bureaucracy put citizens in this online complaint service? and What forms of bureaucratic services are provided so that the public becomes trusted by the government? Both of these questions are important to be answered to ensure that bureaucratic reform can begin by giving trust to the public, and not the other way around by offering good services and then having an impact on increasing public trust.

Several studies on public services begin with a discussion of efforts to increase public trust by improving the quality of public services (Andhika, 2018; Beshi \& Kaur, 2020; Imawan et al., 2019) but it is rarely discussed how bureaucracy starts bureaucratic reform by building trust in citizens. How bureaucracy started to increase trust by opening a wide space for criticism has relatively not been studied much. This study intends to reveal how the government provides public trust as a starting point for reforming the performance of the bureaucracy.

\section{Methods}

This study used a qualitative research method because it aims to see the deepest meaning of the phenomenon of the online complaint mechanism which can be used as the beginning of efforts to improve bureaucratic performance. This study does not want to generalize the object of research for all regions in Indonesia but rather looks at the object under study. Qualitative research can be used to look at public trust development (Pillay, 2017; Twizeyimana \& Andersson, 2019; Zahra et al., 2020).

Public organizations are constantly under severe pressure to produce more value for their communities and environment (Janita \& Miranda, 2018; Loukis et al., 2020; Moussa et 
al., 2018). The focus of this research is to explain how the government or bureaucracy gives trust to the public to convey criticism through online complaint media, and how this can stimulate bureaucratic reform at the local level. To prove that the bureaucracy is serious about giving trust to the public to criticize, the researchers looked for data on online media management. This research is looking for evidence of the number of complaints received, the number of complaints that were completed, how long it took for the complaints to be resolved, and how the complaints were made. Researchers are looking for evidence that the complaint mechanism is simple to use and has a fast response. This study must be able to present data that the online complaint mechanism is simple to use and has a fast response. This is important because simple and fast complaint management can increase external trust in the organization.

Qualitative research has been carried out with interviews, observation, and documentation as data collection techniques. Interviews have been conducted with informants who know and have an interest in the LAB. The informants interviewed in this study included academics, civil servants, and studentactivists who understood the development of LAB services. Observation is carried out by focusing on the important and relevant things on the LAB website page. Observations on the Banyumas complaint booth website were carried out from the beginning of June to 27 June 2020, by observing the number of complaints, the number of complaints that had been responded to, and the speed of the response from the bureaucracy to each complaint report from the public. The number of complaints shows the ease of online complaints provided by the bureaucracy. The number of completed complaints and the speed of response from the bureaucracy show the seriousness and performance of the bureaucracy in managing online complaint media. Data on the number of complaints and the speed of response also show that complaints can turn into pressure and encouragement for the bureaucracy to improve its performance.

Research in maintaining the level of confidence using triangulation of sources, data obtained from interviews, documentation, and observations were compared. One interview result is compared with the interview result, interview result is compared with documentation data and observation result. This technique is used to ensure that every conclusion in this study can be justified and has a high degree of validity.

Data analysis techniques used in this study are content analysis (Kuckartz, 2019) and interactive data analysis (Miles et al., 2014). Content analysis is used to see the meaning that exists in the data contained on the Banyumas complaint stall website, and interactive data are used to analyze field data, namely data from interviews, observation, and documentation. In interactive data analysis techniques, the collected data is condensed or relevant data is collected according to the focus of the research, after which the data is displayed and conclusions are drawn.

\section{Results and Discussion \\ The Certainty of $L A B$ Service}

$L A B$ was officially launched by the Banyumas Regent on October 11, 2018 (Widiyatno, 2018). $L A B$ is a local government communication media that can be utilized by the public to submit complaints or reports regarding services provided by local governments. This is a breakthrough that should be appreciated because, in an increasingly sophisticated era, local governments must also be willing to adapt to changes in the bureaucratic environment. The use of information technology is a necessity in this era.

Government of Banyumas Regency with the existence of this $L A B$ has shown two important things: first, the seriousness and commitment to reform the bureaucracy in the service sector; second, a commitment to adapt to changes in 
the bureaucratic environment. Commitment is important for achieving goals (Wibowo et al., 2019). The seriousness and commitment to bureaucratic reform through $L A B$ is an effort to move or put pressure on the bureaucracy to make changes or improve the quality of public services. Complaints and reports are monitoring mechanisms that can be carried out by the public as service recipients of service providers. Complaints and reports should not be considered threats and attempts to attack the bureaucracy. Instead, complaints and reports are good public intentions to provide input to the government to always learn and improve themselves. Complaints from the public for public organizations can be made as part of efforts to build knowledge of the public so that improvements in institutional performance can be done based on adequate knowledge (Hsieh, 2012; Minelli \& Ruffini, 2018; Parry \& Hewage, 2009; Stauss \& Schoeler, 2004; Vos et al., 2008)“wait times" and "clinical". The latter related to specific concerns about the care provided to the patient or their relative. There were 101 complaints analysed. The majority (60 per cent. Continuous service improvement can be obtained from complaints, and the process of service improvement can be done to control complaints by analyzing the root causes and learning from failures or mistakes (Kumar \& Kumar, 2016).

Second, the $L A B$ is a form of government commitment to always adapt to changes in the bureaucratic environment. When referring to system theory, public organizations are not in a vacuum. They will be greatly influenced by the bureaucratic environment. Public organizations that will survive and thrive are organizations that can carry out social learning processes to adapt to the environment. One form of adapting to the current environment is to utilize the development of science and information technology for bureaucratic reform. The $L A B$ which was designed by utilizing various social media platforms has demonstrated the success of the government to adapt to social and technological changes. Some of the media platforms included in the $L A B$ channel include Twitter, Facebook, and Instagram, with the name lapakaduanbms, email using the address lapakaduanbms@gmail.com, and Whatsapp using the number 08112626116 . This shows that innovation is indeed needed to optimize public services (Aminudin, 2019)so the local goverment can understand more about desires, aspirations and needs of the community compared with the central government who has longer distance from the society. The effort to shortening the distance makes the execution of regional autonomy needs some changes and inovations in giving the service in order to match with the society needs. The result of this research shows that the democratization and regional autonomy policy still can't born the Citizen's Charter in local public service yet, particularly in health care services contract in the Arga Makmur city, North Bengkulu. Realization of the Citizen's Charter principles in the Puskesmas Arga Makmur, North Bengkulu district is proved to have different characteristics with the Citizen's Charter which occurred in Java commonly. In North Bengkulu, the implementation of the Citizen's Charter not only need strong political will from local goverment, budget support (General Revenue and Expenditure Budget/ APBD). Also, governance innovations carried out by the government will have a wide impact not only on the government but also on many groups (Andhika et al., 2018). The government's ability to catch complaints on social media also demonstrates the government's ability to offer convenience to complainants (Istanbulluoglu et al., 2017).

With the existence of this complaint media, the public gets certainty that they have direct access to public service managers with technology that is easily accessible to them. The public with online media like this can easily provide aspirations, input, complaints, and reports on problems they have in the service. With the existence of this $L A B$, the government is trying to show that they are a group that can be trusted in dealing with public 
affairs. After opening this $L A B$ the government also provides certainty of its services, by providing a clear workflow. The clear flow of complaint outlets is proven by the published standards:

1. If there is a complaint, the complaint service officer will respond quickly, no more than 3 hours.

2. After the complaint is entered by the service officer, the complaint will be forwarded to the authorized official with a standard of at most 1 hour.

3. After the complaint is received by the competent official, if it does not require coordination, then no later than 3 working days, the complaint by the competent official will be submitted to the service officer and the response is forwarded to the complainant.

4. After the complaint is received by the competent official, if it requires coordination, then no later than 14 working days, the complaint by the competent official will be submitted to the service officer and the response is forwarded to the complainant.

5. If within 7 days there is no response by the complainant, the complaint is considered complete (see Figure 1).

If it refers to the attitude of complaints from private companies, based on research by Ryngelblum et al. (2013), it was stated that the company would survive and postpone the solution to the complaint, but once they appealed to the consumer protection agency their demands would be granted.

The $L A B$ turned out to be very serious in handling complaints or public reports, this was proven that in the $L A B$ network there were 65 local apparatus organizations or organisasi perangkat daerah (OPD). 65 OPD is all components of government in the Banyumas Regency which include local government agencies, local public companies, vertical agencies, and institutions that take care of public affairs such as Social
Security Administrator or Badan Penyelenggara Jaminan Sosial (BPJS) and religious affairs offices. The ability of the Government of Banyumas Regency to be convinced about the importance of complaints and reports in bureaucratic reform is at an excellent level. It is not easy to bring together many organizations to unite in one service, and that has been done well by the regency government.

$O P D$ s participating in the $L A B$ system can utilize existing information to improve public services. Informant LA1 stated: "Complaints are a means for the bureaucracy to correct distortions as well as to obtain real information on bureaucratic work". Informant LA5 also stated: "In my opinion, with this complaint, this is a form of public supervision because in its implementation the public directly feels the performance of the state apparatus in providing public services, so that an error or violation can be used as an evaluation metric to develop or improve public services in serving the community ". Informant LA11 believes: "Through this complaint, the government can find out the shortcomings of the performance it provides and can immediately correct these deficiencies". Bureaucratic reform can be carried out by utilizing pressure from outside the bureaucracy. Complaints in classical literature have been mentioned as a mechanism for solving problems (Ross \& Littlefield, 1978). This is because, with complaints or reports, organizations can learn about things that need to be improved in terms of service and organizational performance (Hammami \& Triki, 2011). If the complaint mechanism is not managed properly, dissatisfied people can spread their dissatisfaction by word of mouth, and this has a negative impact on the image of the institution (Bolkan, 2018).

\section{Build Citizen Trust with a Trusted Online Complaint System}

In 2019 , the $L A B$ had collected 5347 complaints, the percentage of complaints that 
Figure 1.

Flow of Services in the $L A B$



Source: Adapted from Lapak-Aduan-Banyumas (2020) accessed June 27, 2020

were successfully handled was 5098 complaints or 95 percent of the total complaints. The $L A B$ performance in 2019 thus is at a very good level (See Table 1.)

Table 1 explains that there are three sectors handled at 100 percent, and the lowest response is in the disaster sector at 76,09 percent. As for the 17 sectors, complaints in 8 sectors handled more than 90 percent. Based on the table above, there are two important meanings, first, that the high number of complaints shows that the enthusiasm of citizens to provide suggestions and input to the government is very high. Opening the complaint faucet openly is an effort to give confidence to the public to participate in development. Second, the number of completed complaints shows the seriousness of the government to follow up on citizen complaints and its dedication to always give the best to the public.

$L A B$ is designed with social and technological change that has succeeded in bringing public affairs closer to public character. The public who are familiar with technological developments can easily access this complaint media. In 2019 the most widely used apps to report complaints were WhatsApp (2850) and Facebook (1956). This shows that WhatsApp users submitted the most complaints in 2019.

Table 2 shows that besides through online social media, the regency government also continues to open complaints services offline. Although there are not too many, only 153 complaints, it is important to provide access to citizens who don't use social media to report complaints or reports to local governments. In 2019 the most common service to be handled was complaints sent via Instagram, where 99,17 percent of complaints were successfully handled.

Table 3 shows that the three OPDs that received the most complaints in 2019 were the Transportation Agency, the Public Works Agency, and the Local Water Company. Although the three $O P D$ s received the most complaints, it turned 
Table 1.

Recapitulation of Complaints by Category 2019

\begin{tabular}{clrrr}
\hline No. & \multicolumn{1}{c}{ Categories } & Complaints & Already Handled & Percentage (\%) \\
\hline 1 & Disaster & 46 & 35 & 76,09 \\
2 & Economy and Industry & 34 & 31 & 91,18 \\
3 & Energy & 23 & 23 & 100,00 \\
4 & Infrastructure & 1003 & 989 & 98,60 \\
5 & Staffing & 109 & 95 & 87,16 \\
6 & Population & 491 & 200 & 96,74 \\
7 & Health & 201 & 50 & 99,50 \\
8 & Finance and Assets & 65 & 369 & 76,92 \\
9 & Environment & 380 & 76 & 97,11 \\
10 & Tourism and Culture & 76 & 27 & 100,00 \\
11 & Lokal development & 35 & 105 & 77,14 \\
12 & Education & 114 & 94 & 92,11 \\
13 & Licensing & 98 & 17 & 95,92 \\
14 & Agriculture & 19 & 88 & 89,47 \\
15 & Illegal levies / extortion & 100 & 294 & 88,00 \\
16 & Social & 314 & 2130 & 93,63 \\
17 & Others & 2239 & $\mathbf{5 0 9 8}$ & 95,13 \\
\hline & TOTAL & $\mathbf{5 3 4 7}$ & 95,34 \\
\hline
\end{tabular}

Source: Adapted from Lapak-Aduan-Banyumas (2020) accessed June 27, 2020

Table 2.

Recapitulation of Complaints Based on the Media Platform Used 2019

\begin{tabular}{clrrr}
\hline No. & \multicolumn{1}{c}{ Platform } & Complaints & Already Handled & Percentage (\%) \\
\hline 1 & Twitter & 84 & 82 & 97,62 \\
2 & SP4N_LAPOR & 0 & 0 & 0 \\
3 & Email & 90 & 85 & 94,44 \\
4 & Aduan_Offline & 153 & 147 & 96,08 \\
5 & SMS & 57 & 54 & 94,74 \\
6 & Whatsapp & 2850 & 2718 & 95,37 \\
7 & Instagram & 120 & 119 & 99,17 \\
8 & Website & 37 & 34 & 91,89 \\
9 & Lapor_Gubernur & 0 & 0 & 0 \\
10 & Facebook & 1956 & 1859 & 95,04 \\
\hline & TOTAL & $\mathbf{5 3 4 7}$ & $\mathbf{5 0 9 8}$ & 95,34 \\
\hline
\end{tabular}

Source: Adapted from Lapak-Aduan-Banyumas (2020) accessed June 27, 2020.

out that in the three $O P D s$, complaints were successfully resolved 100 percent. This shows that although their affairs get the most attention from the public, they are able to show that they have a commitment to fulfill public affairs as perfectly as possible. This becomes interesting because there is sometimes bureaucratic behavior that is not in accordance with the directions of the instructions (Ayuningtyas et al., 2018).
If in 2019 the number of complaints received by the regency government was 5.347 , by the middle of 2020 , the number of complaints had increased by almost one hundred percent. As of June 27, 2020, the number of complaints had reached 10.606. This shows that the public feels that the presence of online-based complaints is increasingly being accepted as a medium for interacting with local governments. 
Table 4 shows that the number of complaints that had been successfully handled was 87,97 percent. This figure shows that the performance of regency governments in handling complaints has remained stable to a very good degree.

The three DPOs with the highest number of complaints by mid-2020 are the Transportation Agency, the Public Works Agency, and the Social and Community Empowerment and Village Agency. The number of complaints that were successfully resolved at the Department of Transportation and Public Works was 98,95\% and 98,41 percent, which showed a very good complaint handling performance. As for the handling of complaints at the Social Service and Community and Village Empowerment which is 54,54 percent of the 948 complaints, there are still 431 complaints in process. This is because in these months many people have been affected by Covid 19 and are channeling complaints to local governments. Updates on beneficiary data which is still problematic certainly triggers public dissatisfaction, and this is reflected in many complaints to the Office of Social and Community and Village Empowerment.

The use of social media is important for the government to receive complaints from the public. Until the middle of 2020 the public preferred to use WhatsApp to make a complaint (6.100), and in the second most popular was using Facebook (3.198).

Table 6 shows that the most successful cases handled were complaints through Instagram by 96,66 percent, Twitter and SMS respectively 94,09, and 93,66 percent. The number of complaints completed was 9.330 or 87,97 percent of the total complaints of 10,606 .

\section{Initiating Bureaucratic Reform by Giving Trust Simple Complaints System}

Public services initiated by the Banyumas Regency Government in the form of simple complaint services are interesting to explain. Some facts about the $L A B$ s with simple service are Use of Non-Standard Formats and Languages (Ngapak Local Language)

The format of complaints and non-standard language has already been seen from $L A B$ public

Table 3.

List of $15 O P D$ s that Got the Most Complaints in 2019

\begin{tabular}{clccr}
\hline No. & \multicolumn{1}{c}{ OPD } & Complaints & $\begin{array}{c}\text { Already } \\
\text { Handled }\end{array}$ & Percentage (\%) \\
\hline 1 & Transportation & 1000 & 999 & 99,90 \\
2 & Public Works Service & 750 & 750 & 100,00 \\
3 & Local Water Company & 505 & 505 & 100,00 \\
4 & Population and Civil Registration & 494 & 481 & 97,37 \\
5 & Environmental Services & 349 & 349 & 100,00 \\
& Social Service, Community and Village & 309 & 297 & 96,12 \\
7 & Empowerment & 180 & 180 & 100,00 \\
7 & Satuan Polisi Pamong Praja & 146 & 112 & 76,71 \\
8 & Banyumas Police Department & 146 & 146 & 100,00 \\
9 & State Electricity Company & 135 & 135 & 100,00 \\
10 & Public Health & 124 & 115 & 92,74 \\
10 & Education & 112 & 112 & 100,00 \\
11 & Youth, Sports, Culture and Tourism & 96 & 81 & 84,38 \\
12 & Local Disaster Management Agency & 96 & 94 & 97,92 \\
13 & The One-Stop Integrated Investment and & Licensing Service & 95 & 100,00 \\
14 & BPJS Kesehatan/ Health BPJS & 95 & \\
\hline
\end{tabular}

Source: Adapted from Lapak-Aduan-Banyumas (2020) accessed June 27, 2020. 
Table 4.

Recapitulation of Complaints by Category on June 27, 2020

\begin{tabular}{clccc}
\hline No. & Categories & Complaints & Already Handled & Percentage (\%) \\
\hline 1 & Disaster & 66 & 49 & 74,24 \\
2 & Economy and Industry & 81 & 56 & 69,14 \\
3 & Energy & 51 & 47 & 92,16 \\
4 & Infrastructure & 1884 & 1823 & 96,76 \\
5 & Staffing & 166 & 143 & 86,14 \\
6 & Population & 842 & 791 & 93,94 \\
7 & Health & 502 & 413 & 82,27 \\
8 & Finance and Assets & 120 & 88 & 73,33 \\
9 & Environment & 686 & 658 & 95,92 \\
10 & Tourism and Culture & 107 & 104 & 97,20 \\
11 & Local development & 61 & 48 & 78,69 \\
12 & Education & 236 & 201 & 85,17 \\
13 & Licensing & 180 & 172 & 95,56 \\
14 & Agriculture & 35 & 33 & 94,29 \\
15 & Illegal levies / extortion & 178 & 153 & 85,96 \\
16 & Social & 911 & 551 & 60,48 \\
17 & Others & 4500 & 4000 & 88,89 \\
\hline & TOTAL & $\mathbf{1 0 6 0 6}$ & $\mathbf{9 3 3 0}$ & 87,97 \\
\hline
\end{tabular}

Source: Adapted from Lapak-Aduan-Banyumas (2020) accessed June 27, 2020

Table 5.

15 OPDs with the Most Complaints from January to 27 June 2020

\begin{tabular}{clccr}
\hline No. & \multicolumn{1}{c}{ OPD } & Complaints & $\begin{array}{c}\text { Already } \\
\text { Handled }\end{array}$ & Percentage (\%) \\
\hline 1 & Transportation & 1624 & 1607 & 98,95 \\
2 & Public Works Service & 1449 & 1426 & 98,41 \\
3 & Social Service, Community and Village Empowerment & 948 & 517 & 54,54 \\
4 & Local Water Company & 861 & 858 & 99,65 \\
5 & Population and Civil Registration & 860 & 818 & 95,12 \\
6 & Environmental Services & 635 & 621 & 97,80 \\
7 & Public Health & 490 & 392 & 80,00 \\
8 & Satuan Polisi Pamong Praja & 362 & 362 & 100,00 \\
9 & Banyumas Police Department & 290 & 251 & 86,55 \\
10 & State Electricity Company & 286 & 270 & 94,41 \\
11 & Education & 277 & 237 & 85,56 \\
12 & Bupati Banyumas Regent of Banyumas & 245 & 128 & 52,24 \\
13 & The One-Stop Integrated Investment and Licensing & 205 & 199 & 97,07 \\
14 & Yervice & 182 & 179 & 98,35 \\
15 & The Local Secretariat & 162 & 144 & 88,89 \\
\hline
\end{tabular}

Source: Adapted from Lapak-Aduan-Banyumas (2020) accessed June 27, 2020

service announcements. This offline complaint ad for example states: "siki lapak aduan wis ana neng mal pelayanan publik. mayuh, mbok pada arep mengadu utawane arep laporan, bisa maring ngeneh" ("now complaints outlets can be served at the Public Service Mall. Come on, if you will complain or make a report, you can come here"). The egalitarian language of Ngapak seems to give a message, don't hesitate to make a report, we are your friends. This message also gives the 
Table 6.

Recapitulation of Complaints Based on Media Platform Used from January to 27 June 2020

\begin{tabular}{clrrr}
\hline No. & \multicolumn{1}{c}{ Platform } & Complaints & Already Handled & Percentage (\%) \\
\hline 1 & Twitter & 220 & 207 & 94,09 \\
2 & SP4N_LAPOR & 67 & 38 & 56,72 \\
3 & Email & 159 & 137 & 86,16 \\
4 & Aduan_Offline & 184 & 175 & 95,11 \\
5 & SMS & 142 & 133 & 93,66 \\
6 & Whatsapp & 6.100 & 5.300 & 86,89 \\
7 & Instagram & 235 & 227 & 96,60 \\
8 & Website & 52 & 48 & 92,31 \\
9 & Lapor_Gubernur & 249 & 186 & 74,70 \\
10 & Facebook & 3.198 & 2.879 & 90,03 \\
\hline & TOTAL & $\mathbf{1 0 . 6 0 6}$ & $\mathbf{9 . 3 3 0}$ & 87,97 \\
\hline
\end{tabular}

Source: Adapted from Lapak-Aduan-Banyumas (2020) accessed June 27, 2020

Table 7.

Examples of $L A B S$ in the use of local languages that received a quick response:

\begin{tabular}{|c|c|}
\hline Complaints or Question & The Answer From the Authorized $O P D$ \\
\hline Asking the tourism & From: Youth, Sports, Cul \\
\hline & r \\
\hline $\begin{array}{l}\text { Sent via WhatsApp - } 27 \text { 10:03:36 Juni 2020, Tourism } \\
\text { and Culture Category: }\end{array}$ & $\begin{array}{l}\text { ing the } \\
\text { ter tour }\end{array}$ \\
\hline $\begin{array}{l}\text { Tempat wisata renang sing wis di bukak endi ya? } \\
\text { Maturnuwun atas informasine } \\
\text { (Where is the open-air swimming pool? thank you for } \\
\text { the information) }\end{array}$ & $\begin{array}{l}\text { allowed to open. Even in the Circular on preventing } \\
\text { Covid - } 19 \text { in the tourism sector and tourist villages, } \\
\text { tourism objects are permitted to open but in them, } \\
\text { water or swimming pools should not be operated. }\end{array}$ \\
\hline ght of light roads a & \\
\hline $\begin{array}{l}\text { over the road of sun } \\
\text { nanas } \quad \# \mathbf{f} \mathbf{2 0 0 0 0 0}\end{array}$ & $\mathrm{R}$ \\
\hline 13:46:27 Juni 2020, & \\
\hline Min aku arep usul. sepanjang dalan Sunan 1 & LPJU \\
\hline jaga Berkoh - Karang Nanc & ue to the \\
\hline lintas ramai pejalan lewat. mbok ya di sogini lan & \\
\hline pene & \\
\hline $\begin{array}{l}\text { from Berkoh to Karang Nanas if the night is } \\
\text { n though it is busy. If you can be given street }\end{array}$ & $\begin{array}{l}\text { lllage musrenbang so that it can be } \\
\text { g }\end{array}$ \\
\hline
\end{tabular}

Source: Lapak-Aduan-Banyumas (2020) accessed June 27, 2020.

impression that reporting is not complicated, just report it, using the Ngapak language is also not a problem. The public can access this complaint system through a variety of existing social media: facebook (@lapakaduanbms), instagram (@lapakaduanbms),twitter (@ lapakaduanbms), WhatsApp (08112626116), email (lapakaduanbms@gmail.com), Telephone (08112626116), and admin (lapakaduan@ banyumaskab.go.id).
The second ad reinforces the first ad, this ad reads: "Pak Bupati, nyong dea, bocah pliken no KTP ne nyong 330225xхxхxхx kiye deneng lampu dalane ana sing sipet, tulung didandani lah...suwun". This ad reads: "Mr. regent, I am dea, child pliken my ID number, 330225xxxxxx. this is a streetlight that is off, please fix it ... thanks". Message format like this shows that to report one does not need to use formal lanugage or format. Reports can be made as simple as possible, according to the style and abilities of 
the public. The government gives the message, don't hesitate to report in any language. The language of this advertisement was made without regard to standard Indonesian grammar because it really wanted to show that the $L A B$ was for the public, and the public itself determined how they wanted to communicate with the government.

Based on observations on the website http://lapakaduan.banyumaskab.go.id/ it can be seen that the manager's response to the report in the Ngapak language is good. Managers still process complaints in the local language with a relatively fast time. Some examples of complaints about language and being responded to quickly by the $L A B$ manager are:

The use of local languages that appear egalitarian and reflect informality according to the informants is a good thing. The statement of the informant stating that he supported the use of local languages in complaints in the $L A B$ is summarized in the following table 8:

Public trust can be built by managing a complaint mechanism as well as possible. Aspects of the communication process that are running well, will cause credibility amongst the public so that government trust can be built both online and through word of mouth (Breitsohl et al., 2010; Singh et al., 2016). The use of Ngapak language with humor can be an asset to build a positive government image so the public believes agencies can be trusted to receive a variety of complaint styles. Even so, an organization must pay attention to funny replies to complainants or complaints (Shin \& Larson, 2020).

One of the jumps in terms of public services on the $L A B$ is that the public is not required to attach evidence to the report. Every report that comes in is believed to be valuable information. The government is tasked with verifying the data, providing answers, and providing solutions to problems owned by individuals or the public. The process of gathering information from customers or the public is important (Wirtz \& Lwin, 2009) which in the past have been examined in isolation. In the present study, regulatory focus theory is used to integrate both approaches and examine their distinct response behaviors concurrently. The findings are robust across two studies with

Table 8.

Statements of Informants Regarding Local Languages in $L A B$

\begin{tabular}{|c|c|}
\hline Informant & Statements \\
\hline Informant LA1 & $\begin{array}{l}\text { "The form of respect for local wisdom as well as the closer social distance between the } \\
\text { government and its citizens. Also, build familiarity with Banyumas residents". }\end{array}$ \\
\hline Inform & $\begin{array}{l}\text { "The use of local languages is one of the strategies or ways that the community can play an } \\
\text { active role in the process of bureaucratic reform in Banyumas Regency, with the use of local } \\
\text { languages, of course, the community will be easier and more willing to participate". }\end{array}$ \\
\hline Inform & $\begin{array}{l}\text { "This is a good thing because not all people are able to use Indonesian, so the freedom to use } \\
\text { local languages in complaints greatly facilitates the community". }\end{array}$ \\
\hline Inform & $\begin{array}{l}\text { "The face of the bureaucracy that we knew before tends to be stiff. (With) the use of local } \\
\text { languages in reporting complaints, I value as a form of creating a bureaucracy image that is } \\
\text { more humane and united with the community". }\end{array}$ \\
\hline Inform & $\begin{array}{l}\text { "In my opinion, using local languages can reach Banyumas people especially those who cannot } \\
\text { use the formal EYD language structure". }\end{array}$ \\
\hline Inform & $\begin{array}{l}\text { "The local government is increasingly popular, by understanding the culture of the Banyumas } \\
\text { people" }\end{array}$ \\
\hline Informa & $\begin{array}{l}\text { "Very interesting and also good. This can make it easier for the community, and be } \\
\text { straightforward to express their complaints or express their feelings without being burdened } \\
\text { with the provisions of using the Indonesian language properly and correctly or following the } \\
\text { provisions of the EYD. In addition, the use of local languages shows the egalitarian culture of } \\
\text { Banyumas people and the absence of a barrier between the government and the community". }\end{array}$ \\
\hline
\end{tabular}

Source: Data Processed 2020 
Table 9.

Examples of Simple Complaints

\begin{tabular}{|c|c|}
\hline Complaints or Question & The Answer From the Authorized $O P D$ \\
\hline $\begin{array}{l}\text { Complaints about making KTP (resident identification } \\
\text { card) \#w2000002751 Sent via WhatsApp - } 27 \text { 08:30:28 } \\
\text { Juni 2020, Population Category } \\
\text { "pagi bos admin,,nek kaya kye anu priwe ya bos ? masa gawe } \\
\text { ktp e uis } 2 \text { minggu ra dadi2" } \\
\text { ("Good morning Boss Admin, what exactly is this Boss? make } \\
\text { a KTP has not been finished in } 2 \text { weeks") }\end{array}$ & $\begin{array}{l}\text { Klik kirim ndorooo ..... kuwe durung kirim } \\
\text { permohonannya, ya nda bakal terproses } \\
\text { ("Click send, Sir ... if the request has not been sent, } \\
\text { it will not be processed") }\end{array}$ \\
\hline $\begin{array}{l}\text { Local water company dies in Jl. Pamujan \#w2000002747 } \\
\text { Sent via WhatsApp - } 26 \text { 18:37:03 Juni 2020, Other } \\
\text { Categories }\end{array}$ & $\begin{array}{l}\text { From: Local Water Company } \\
\text { Reply on June } 26,2020,19: 29: 19\end{array}$ \\
\hline $\begin{array}{l}\text { Assalamualaikum wr.wb, good evening ladies and } \\
\text { gentlemen at the place, I am ***** Address: Jl. Pamujan baru } \\
\text { III no.103 rt / rw: } 05 / 10 \text { Teluk Want permission to submit } \\
\text { (complaints) at the same time ask, Why PDAM (water) } \\
\text { every day of death? Even though the pandemic is like this, } \\
\text { it should be smooth for cleaning together, if you want to } \\
\text { wash, there's no running water, how do you want to be } \\
\text { healthy, Sir? Please help, ladies and gentlemen, what's the } \\
\text { solution, because every day the water dies. I have already } \\
\text { contacted the regent and vice (regent), he said to contact } \\
\text { this number, That's all, and thank you... Okay, thank you, } \\
\text { ladies and gentlemen, healthy always.. }\end{array}$ & $\begin{array}{l}\text { Good evening, thank you for the information, we } \\
\text { will immediately follow up with TS. } \\
\text { Local Water Company } \\
\text { Follow Up on June 26, 2020, 00:00:00 } \\
\text { Information Appointment and cleaning of the } \\
\text { intake pump screen has been completed, Re- } \\
\text { production using } 4 \text { booster pumps. Thank you. }\end{array}$ \\
\hline
\end{tabular}

Source: Lapak-Aduan-Banyumas (2020) accessed June 29, 2020

different methods and contexts. As suggested in the proposed model, trust and privacy concern are the two central mediating variables with differentiated effects on promotion and prevention-focused behaviors. Specifically, trust mediates fairness perceptions on promotion-focused behaviors (i.e., relational behavior, relationship investment, and repatronage intentions.

The government with this $L A B$ format makes the public not hesitate to ask questions related to public services. Complaints submitted also vary from just requesting information, to proposals and questions.

Table 10.

Types of Contacts January - June 28, 2020

\begin{tabular}{lrr}
\hline Type of Contacts & Amount & Percentage \% \\
\hline Information & 2.240 & 21,1 \\
Suggestion & 1.474 & 13,9 \\
Question & 2.621 & 24,7 \\
Complaint & 4.278 & 40,3 \\
\hline
\end{tabular}

Source: Lapak-Aduan-Banyumas (2020) accessed June 28, 2020
Table 10 shows that most contacts were related to complaints as many as 4278 complaints or 40,3 percent of the total complaints from January to 28 June 2020 . This shows that the $L A B$ is a media that is considered easy to submit about complaints. In addition to complaints, $L A B$ is also used by residents as an effort to share information with local governments. The Informant LA12 stated: "Local governments will always accept every report without showing how the report was made. This is an extraordinary leap in the bureaucracy. Bureaucracy has always been known to be bureaucratic, including in this case the report format that must be appropriate. If it is not in the format, then the complaint report is not suitable to be followed up. This was intended to be reformed by the Banyumas Regency Government, that the public still has the right to complain, give aspirations, provide criticism and input to the government. The government is tasked with attracting as much input from the public as 
capital to improve government services to the public". This shows that when citizens are given the confidence to interact with the government, some of the citizens are citizens in good faith to convey information that may not yet be known by the government related to public services. There are 2240 information requests received by the government from citizens. In addition to information, the public also makes $L A B$ as a medium to provide their aspirations. It is proven that 1474 or around 13, 9 percent of complaints received by the Banyumas Regency Government from January to 28 June 2020 were in the form of proposals. This reinforces that citizens who are entrusted will provide many ideas to the government in terms of improving the quality of services. The organization must pay serious attention to complaints, and for each complaint, the service provider must respect their needs (Gruber, 2011).

The New Public Service perspective, which puts more of an emphasis on citizens, wants to encourage public services to focus on improvement to better serve citizens (Denhardt \& Denhardt, 2003). This means that public services must be oriented towards improving public services to benefit the citizens. Complaints, information requests, questions, and reports sent by the public to the government are valuable things to drive changes in the internal bureaucracy. This becomes important for the bureaucracy because now their accountability is not only on the internal bureaucracy, but the public as an external-independent supervisor will always look at the performance of the bureaucracy in detail and care. Bureaucracy can no longer be silent with problems faced by the public. Dynamic bureaucracy must be pushed into the face of Indonesia's future bureaucracy. A dynamic bureaucracy is a bureaucracy that can think again, think ahead, and think across (Neo \& Chen, 2007). A "thinking again" bureaucracy must be able to rethink its activities whether any of its activities must change with the times. The bureaucracy that thinks ahead is a bureaucracy that can think futuristically, able to predict the future so that the current activity is driven by the vision of becoming a winner in the future. A bureaucracy that thinks across is a bureaucracy that can penetrate routine boundaries, bureaucracy can think outside the box so that innovation and creation will be able to emerge to solve increasingly complex problems and public demands..

\section{Quick Response}

$\mathrm{LAB}$ which has given the trust to the public to provide input for the improvement of public services is consistent to respond to the public response. The governmentss rapid response to public complaints is a form of good commitment from the LAB. The LAB response in responding to public complaints is at a very good level.

Table 11.

Response time and number of responses from January to 28 June 2020

\begin{tabular}{lcr}
\hline Duration of Response & $\begin{array}{r}\text { Number of } \\
\text { responses }\end{array}$ & Persentage \\
\hline $\begin{array}{l}\text { Complaints Response }<3 \\
\text { hours }\end{array}$ & 4.034 & 38,20 \\
$\begin{array}{l}\text { Complaints Response }> \\
3 \text { hours }\end{array}$ & 1.848 & 17,50 \\
$\begin{array}{l}\text { Complaints Response }> \\
1 \text { day }\end{array}$ & 3.408 & 32,3 \\
Complaint In Progress & 1.276 & 12,1 \\
\hline
\end{tabular}

Source: Lapak-Aduan-Banyumas (2020) accessed June 28, 2020

Table 11 shows that during the first half of 2020, complaints that were responded to in less than 3 hours were 4034 complaints or 38,20 percent. This means that most reports are responded to in less than 3 hours. Informant LA1 stated that "this is proof that the Banyumas bureaucracy is serious about providing public services. It also shows the horizontal accountability that is being built by the bureaucracy towards the citizens served ". Informant LA4 also stated "very good, LAB was 
quite responsive in solving problems that were complained of by the community». Informant LA5 stated «LAB is a new innovation initiated by the Government of Banyumas Regency in its efforts to improve the public service sector. Based on the data, I judge that there has been progress made through the program. However, that does not mean that progress has been made in the satisfactory category. For this reason, strict and intensive supervision is needed, from both the government and the community. With this control, it is expected that the minimum service standards can be maintained and if necessary continue to be improved». Based on the above data it can be concluded that the LAB is able to show good performance in managing citizen complaints. This also explicitly shows that LAB gives citizens the trust to supervise the government, in this case, it is to submit complaints related to public services and public affairs.

Based on empirical evidence, one of the things that can be considered to understand the mechanism of building trust is prior experience and reputation (de Araujo \& Franco, 2017). Therefore, providing a good customer experience by completing each complaint with a rapid response conceptually can increase trust in leaders and public organizations because the mechanism to increase public trust in local governments is credibility, fairness, respect, and communication (Ohemeng et al., 2019). In addition, the members of the public who follow the progress of complaints on the $L A B$ website can provide a positive or negative response to the complaint manager. Research shows that someone will respond negatively if they see that the complaint process is not responded to well by the service provider (Kim \& Baker, 2020).

An essential finding from this research is that efforts to increase public trust can be done by offering citizens an easy to use system to file a complaint. Simple complaint mechanisms and quick response are the government's commitment to make it a starting point for improving bureaucratic performance (bureaucratic reform). The criticism and input that has been given by the public will push the bureaucracy to change. If the performance of the bureaucracy changes for the better, then automatically public trust in the government will increase. The online complaint mechanism in Banyumas Regency at least provides evidence that the local government can take the initiative to put pressure on improving bureaucratic performance at the local level.

Figure 2.

The framework initiates bureaucratic reform by giving trust to the public with a complaint mechanism

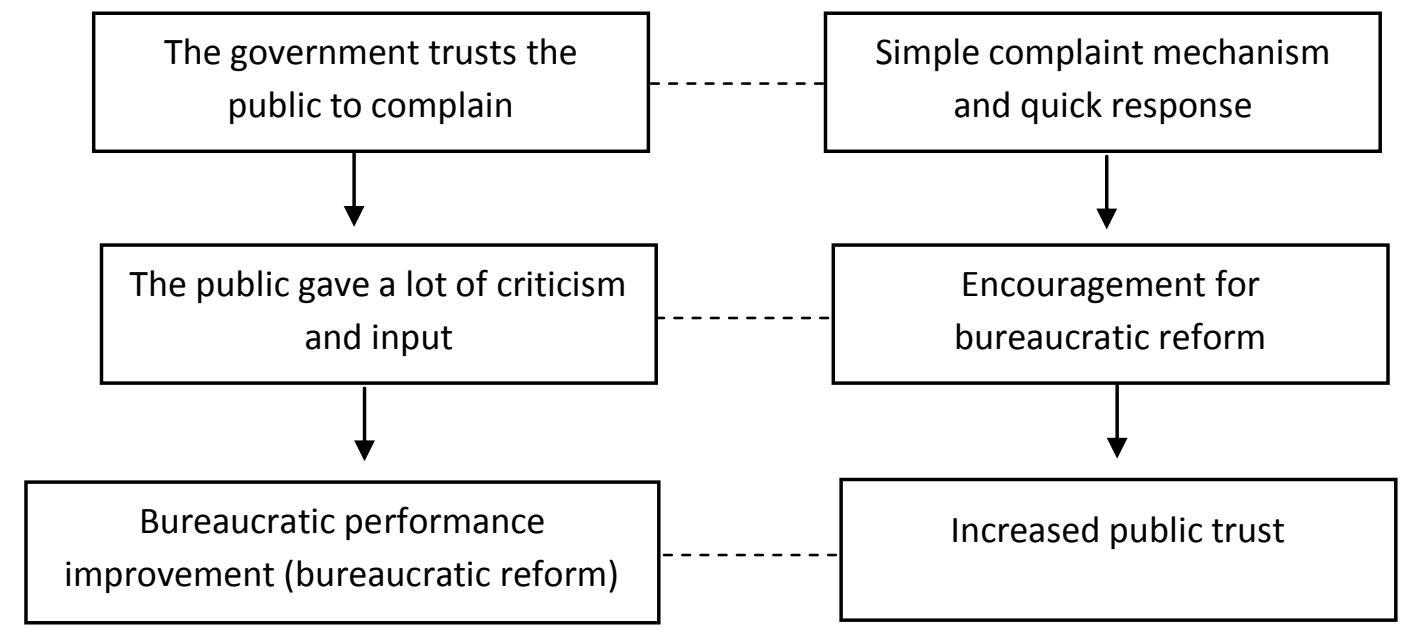

Source: Processed data (2020) 
The evidence that bureaucracy can improve performance is that in 2019, 95 percent of the complaints were resolved, and until June of 2020, 87 percent of complaints were resolved, 38 percent were completed in less than 3 hours, 17.5 percent were completed more than three hours, and 32.3 percent were completed in more than a day. This shows a better bureaucratic performance after the complaint mechanism exists.

\section{Conclusion}

Simple online complaint mechanisms with a quick response from the bureaucracy are forms of government trust in the public. A simple complaint format in the local language (Ngapak) without the need to use an official format has stimulated the public not to feel awkward about making a report to the local government. The local government in this case has made an extraordinary leap in changing the image of the bureaucracy which was originally rigid to become a familiar and populist institution that serves the public. Improved services resulting from public complaints shows that giving public trust can be a starting point for bureaucratic reform at the local level. By utilizing the development of information technology, local governments can receive more complaints from the public and give a faster response than using manual forms. This also shows that the use of information technology has been beneficial in encouraging public participation and improving the quality of public services. This research recommends the government to continue to increase the public's trust in public services. The public's trust can be increased by making forms and terms of service as simple as possible, and utilizing information technology to facilitate procedures for accessing public services.

\section{References}

Aminudin, A. (2019). Democratize Health Policy Through Citizen's Charter in North Bengkulu District. Policy \& Governance Review, 2(3),
232-244. https://doi.org/10.30589/pgr. v2i3.103

Andhika, L. R. (2018). Meningkatkan Kepercayaan Publik Terhadap Pemerintah Melalui Redesain Proses Kebijakan. Jurnal Ilmu Pemerintahan : Kajian Ilmu Pemerintahan Dan Politik Daerah, 3(1), 24. https://doi. org/10.24905/jip.v3i1.831

Andhika, L. R., Nurasa, H., Karlina, N., \& Candradewini, C. (2018). Logic Model of Governance Innovation and Public Policy in Public Service. Policy \& Governance Review, 2(2), 85-98. https://doi.org/10.30589/pgr.v2i2.86

Ayuningtyas, D., Rayhani, M., Misnaniarti, M., \& Maulidya, A. N. (2018). Implementation of Mental Health Policies toward Indonesia Free Restraint. Policy \& Governance Review, 2(2), 161-173. https://doi.org/10.30589/ pgr.v2i2.85

Beshi, T. D., \& Kaur, R. (2020). Public Trust in Local Government: Explaining the Role of Good Governance Practices. Public Organization Review, 20(2), 337-350. https://doi. org/10.1007/s11115-019-00444-6

Bolkan, S. (2018). Threat, Coping, and Cost: Protection Motivation in the Context of Consumer Complaining. Communication Research, 45(6), 840-861. https://doi. org/10.1177/0093650215600492

Breitsohl, J., Khammash, M., \& Griffiths, G. (2010). E-business complaint management: Perceptions and perspectives of online credibility.Journal of Enterprise Information Management, 23(5), 653-660. https://doi. org/10.1108/17410391011083083

Brennan, C., \& Douglas, A. (2002). Complaints procedures in local government: Informing your customers. International Journal of Public Sector Management, $15(3), 219-236$. https://doi . org/10.1108/09513550210414569

de Araujo, D. von B., \& Franco, M. (2017). Trustbuilding mechanisms in a coopetition 
relationship: a case study design. International Journal of Organizational Analysis, 25(3), 378-394. https://doi. org/10.1108/IJOA-04-2016-1012

Denhardt, J. V., \& Denhardt, R. B. (2003). The New Public Service: Serving, Not Steering. M.E. Sharpe, Inc.

Gruber, T. (2011). I want to believe they really care: How complaining customers want to be treated by frontline employees. Journal of Service Management,22(1),85-110. https:// doi.org/10.1108/09564231111106938

Hammami, S. M., \& Triki, A. (2011). Exploring the information technology contribution to service recovery performance through knowledge based resources. Vine, 41(3),296-314.https:// doi.org/10.1108/03055721111171627

Hsieh, S. Y. (2012). Using complaints to enhance quality improvement: Developing an analytical tool. International Journal of Health Care Quality Assurance, 25(5), 453-461. https://doi. org/10.1108/09526861211235946

Imawan, A., Irianto, G., \& Prihatiningtias, Y. W. (2019). Peran Akuntabilitas Pemerintah Desa Dalam Membangun Kepercayaan Publik. Jurnal Akuntansi Multiparadigma, 10(1). https://doi.org/10.18202/ jamal.2019.04.10009

Istanbulluoglu, D., Leek, S., \& Szmigin, I. T. (2017). Beyond exit and voice: developing an integrated taxonomy of consumer complaining behaviour. European Journal of Marketing, 51(5-6), 1109-1128. https:// doi.org/10.1108/EJM-04-2016-0204

Janita, M. S., \& Miranda, F. J. (2018). Quality in e-Government services: A proposal of dimensions from the perspective of public sector employees. Telematics and Informatics, 35(2), 457-469. https://doi. org/10.1016/j.tele.2018.01.004

Kim, K., \& Baker, M. A. (2020). The Customer Isn't Always Right: The Implications of
Illegitimate Complaints. Cornell Hospitality Quarterly, 61(2), 113-127. https://doi. org/10.1177/1938965519889288

Kuckartz, U. (2019). Qualitative Text Analysis: A Systematic Approach. Springer International Publishing. https://doi.org/10.1007/9783-030-15636-7_8

Kumar, M., \& Kumar, N. (2016). Three dimensions of service recovery: examining relationship and impact. Supply Chain Management, 21(2), 273-286. https://doi.org/10.1108/ SCM-03-2015-0086

Lanin, D., \& Hermanto, N. (2019). The effect of service quality toward public satisfaction and public trust on local government in Indonesia. International Journal of Social Economics, 46(3), 377-392. https://doi. org/10.1108/IJSE-04-2017-0151

Lapak-Aduan-Banyumas. (2020). Lapak Aduan Banyumas. http://lapakaduan. banyumaskab.go.id/

Loukis, E. N., Maragoudakis, M., \& Kyriakou, N. (2020). Artificial intelligence-based public sector data analytics for economic crisis policymaking. Transforming Government: People, Process and Policy. https://doi. org/10.1108/TG-11-2019-0113

Miles, M. B., Huberman, A. M., \& Saldana, J. (2014). Qualitative Data Analysis: A Methods Sourcebook and The Coding Manual for Qualitative Researchers. SAGE.

Minelli, A., \& Ruffini, R. (2018). Citizen feedback as a tool for continuous improvement in local bodies. International Journal of Public Sector Management, 31(1), 46-64. https:// doi.org/10.1108/IJPSM-01-2017-0010

Moussa, M., McMurray, A., \& Muenjohn, N. (2018). A Conceptual Framework of the Factors Influencing Innovation in Public Sector Organizations. The Journal of Developing Areas, 52(3), 231-240. https://doi. org/10.1353/jda.2018.0048 
Neo, B. S., \& Chen, G. (2007). Dynamic Governance: Embedding Culture Capabilities and Chande in Singapura. World Scientific Publishing Co. Pte. Ltd.

Nulhusna, R., Sandhyaduhita, P. I., Hidayanto, A. N., \& Phusavat, K. (2017). The relation of e-government quality on public trust and its impact on public participation. Transforming Government: People, Process and Policy, 11(3), 393-418. https://doi. org/10.1108/TG-01-2017-0004

Nurhidayati, D. (2019). Does Digital Public Service Complaint Promote Accountability? A Comparative Analysis of Upik Yogyakarta and Qlue Jakarta. Policy \& Governance Review, 3(2), 127-141. https://doi. org/10.30589/pgr.v3i2.139

Ohemeng, F. L. K., Obuobisa Darko, T., \& AmoakoAsiedu, E. (2019). Bureaucratic leadership, trust building, and employee engagement in the public sector in Ghana. International Journal of Public Leadership, 16(1), 17-40. https://doi.org/10.1108/ijpl-05-20190018

Parry, J., \& Hewage, U. (2009). Investigating complaints to improve practice and develop policy. International Journal of Health Care Quality Assurance, 22(7), 663-669. https:// doi.org/10.1108/09526860910995001

Pillay, P. (2017). Public trust and good governance : a comparative study of Brazil and South Africa. African Journal of Public Affairs, 9(8), 31-47.

Pramusinto, A. (2014). Building Complaint Handling Mechanisms For Effective Leadership. Bisnis \& Birokrasi Journal, 20(3), 144-152. https://doi.org/10.20476/ jbb.v20i3.3203

Ross, H. L., \& Littlefield, N. O. (1978). Complaint as a Problem-Solving Mechanism. Law \& Society Review, 12 (2 (Winter, 1978)), 199-216.
Ryngelblum, A. L., Vianna, N. W. H., \& Rimoli, C. A. (2013). The ways companies really answer consumer complaints. Marketing Intelligence and Planning, 31(1), 54-71. https://doi. org/10.1108/02634501311292920

Shin, H., \& Larson, L. R. L. (2020). The bright and dark sides of humorous response to online customer complaint. European Journal of Marketing. https://doi.org/10.1108/EJM08-2018-0522

Singh, V., Jain, A., \& Choraria, S. (2016). Exploring the Role of Complaint Handling among Complaining Consumers. Vision, 20(4), 331-344. https://doi. org/10.1177/0972262916668739

Stauss, B., \& Schoeler, A. (2004). Complaint management profitability: What do complaint managers know? Managing Service Quality: An International Journal, 14(2), 147-156. https://doi. org/10.1108/09604520410528572

Twizeyimana, J. D., \& Andersson, A. (2019). The public value of E-Government - A literature review. Government Information Quarterly, 36(2), 167-178. https://doi.org/10.1016/j. giq.2019.01.001

Vos,J.F.J., Huitema, G. B., \& Lange-Ros, E. (2008). How organisations can learn from complaints. The TQM Journal, 20(1), 8-17. https://doi. org/10.1108/09544780810842866

Wibowo, Y. S., Luddin, M. R., \& Sari, E. (2019). Understanding Organizational Commitments in the Public Sector: A Case Study of Commissioners and Investigators at The Business Competition Supervisory Commission (KPPU). Policy \& Governance Review, 3(3), 208-224. https://doi. org/10.30589/pgr.v3i3.152

Widiyatno, E. (2018). Pemkab Banyumas Luncurkan LapakAduan. https://republika.co.id/berita/ nasional/daerah/18/10/11/pgfh5j368pemkab-banyumas-luncurkan-lapak-aduan 
Wirtz, J., \& Lwin, M. O. (2009). Regulatory focus theory, trust, and privacy concern. Journal of Service Research, 12(2), 190-207. https:// doi.org/10.1177/1094670509335772

Zahra, B. F., Oly, N. N., Sachin, K., Egide, K. G., \& Diane, P. (2020). Building trust in multi- stakeholder collaborations for new product development in the digital transformation era. Benchmarking: An International Journal, 28(1), 205-228. https://doi.org/10.1108/ BIJ-04-2020-0164 